\title{
EFEK FRAKSI AKTIF DAUN GENDOLA (BASELLA ALBA) TERHADAP JUMLAH SPERMA DAN KADAR HORMON TESTOSTERONE TIKUS PUTIH JANTAN (RATTUS NORVEGICUS)
}

\section{Fitrianti Yuni}

Universitas Sriwijaya Palembang, Indonesia

Email: yuni.handani30@gmail.com

\begin{abstract}
Abstrak
Faktor Pria merupakan 30\% faktor penyebab infertilitas pada PASUTRI di masa produktif. Telah banyak usaha yang dilakukan untuk mengatasi infertilitas pada pria, salah satunya dengan penggunaan obat penyubur atau afrodisiak yaitu daun gendola. Tujuan penelitian, untuk mengetahui efektivitas fraksi aktif daun gendola terhadap jumlah spermatozoa dan kadar hormone testosterone tikus jantan (Rattus norvegicus). Penelitian ini diadakan pada bulan Agustus - November 2020 di Fakultas Kedokteran Universitas Sriwijaya. Penelitian ini menggunakan Post Test Only Control Group Design. Hewan uji yang dipakai sebanyak 33 ekor terbagi secara random dalam 11 kelompok perlakuan. Tiap kelompok terdiri atas 3 ekor tikus dengan rincian kelompok diberi n-heksan $1 \mathrm{mg} / \mathrm{kgBB}$, n-heksan $5 \mathrm{mg} / \mathrm{kgBB}$, fraksi n-heksana dosis $10 \mathrm{mg} / \mathrm{kgBB}$, fraksi etil asetat dosis $1 \mathrm{mg} / \mathrm{kgBB}$, fraksi etil asetat $5 \mathrm{mg} / \mathrm{kg} \mathrm{BB}$, fraksi etil asetat dosis $10 \mathrm{mg} / \mathrm{kgBB}$, fraksi methanol air dosis 1 $\mathrm{mg} / \mathrm{kgBB}$, fraksi methanol air dosis $5 \mathrm{mg} / \mathrm{kgBB}$, fraksi methanol air dosis 10 $\mathrm{mg} / \mathrm{kgBB}$ diberikan secara oral selama 30 hari. kelompok kontrol negative diberikan Na CMC 1\% sebanyak 1 cc secara oral selama 30 hari. Kelompok kontrol dengan diberikan Testosteron Enanthate dengan dosis $5 \mathrm{mg} / \mathrm{kgBB}$ yang dilarutkan dengan sesame oil / minyak wijen sebanyak 1 cc secara injeksi intramuscular di paha tikus. Terdapat peningkatan kadar hormone testosterone dan jumlah spermatozoa pada tikus jantan setelah pemberian fraksi aktif daun gendola bila dibandingkan dengan testosterone enanthate dan Na CMC 1\%. Dalam penelitian ini menyatakan bahwa fraksi Basella alba berperan dalam meningkatkan kesuburan tikus jantan.
\end{abstract}

Kata Kunci: kesuburan, testosterone, jumlah spermatozoa fraksi, basella alba.

\section{Abstract}

Infertility is $30 \%$ caused by male problems. There are so many ways to solve this, one of them is taking traditional medicine, gendola leaves. This research was aim to analyze the effect of gendola leaves to increase sperms count and testosterone in male rat (Rattus norvegicus). This study was conducted in Medical Faculty of Sriwijaya University on August until November 2020. The rats were classified to 11 groups which consist of 3 rats. They were given fraction suspension of gendola leaves for 30 days per oral in doses $n$-hexan $1 \mathrm{mg} / \mathrm{kgBB}$, $n$-hexane $5 \mathrm{mg} / \mathrm{kgBB}, \mathrm{n}$ hexane $10 \mathrm{mg} / \mathrm{kgBB}$, ethyl acetate $1 \mathrm{mg} / \mathrm{kgBB}$, ethyl acetate $5 \mathrm{mg} / \mathrm{kgBB}$, ethyl

$\begin{array}{ll}\text { How to cite: } & \text { Yuni. F (2022) Efek Fraksi Aktif Daun Gendola (Basella Alba) Terhadap Jumlah Sperma dan Kadar Hormon } \\ & \text { Testosterone Tikus Putih Jantan (Rattus Norvegicus). Syntax Literate: Jurnal Ilmiah Indonesia, 7(1). } \\ & \text { http://dx.doi.org/10.36418/ Syntax-Literate.v7i1.5652 } \\ \text { E-ISSN: } & \text { 2548-1398 } \\ \text { Published by: } & \text { Ridwan Institute }\end{array}$


acetate $10 \mathrm{mg} / \mathrm{kgBB}$, methanol-water fraction $1 \mathrm{mg} / \mathrm{kgBB}$, methanol-water dosis 5 $\mathrm{mg} / \mathrm{kgBB}$, methanol-water $10 \mathrm{mg} / \mathrm{kgBB}$ given in 30 days. As a negative control given Sodium Carboxymethil Cellulose $1 \%$ per oral for 30 days.As a positive control given testosterone enanthate $5 \mathrm{mg} / \mathrm{KGBB}$ on 0 day and 12 day. There was increased of testosterone and sperm counts after given fraction of Basella alba for 30 days compared to testosterone enanthate and Na CMC 1\%. in this study we can conclude that fraction of gendola leaves increase male fertility

Keywords: fertility, testosterone, sperm counts, fraction, Basella alba

Received: 2021-12-20; Accepted: 2022-01-05; Published: 2022-01-15

\section{Pendahuluan}

Infertilitas masih merupakan salah satu masalah kesehatan yang menjadi momok bagi pasangan suami istri. Infertilitas merupakan ketidakmampuan pasangan suami istri untuk memiliki anak setelah melakukan aktivitas seksual secara aktif selama satu tahun tanpa menggunakan alat kontrasepsi (WHO, 2012).

Prevalensi infertilitas di dunia secara global pada tahun 2010 sekitar 50-80 juta jiwa atau 8-10 \% pasangan usia subur. Menurut Badan Pusat Statistik bahwa ada sekitar 10-15\% pasangan infertil dari total 237 juta penduduk Indonesia (BPS, 2013). Penelitian di Palembang, Sumatera Selatan terhadap 246 pasangan infertil menunjukkan faktor pria sebagai penyebab infertilitas sebesar 48,4\% (Pasaribu, Lubis, Arsyad, Barus, \& Sutanto, 1987).

Infertilitas dapat disebabkan oleh $30 \%$ gangguan pada pria, $60 \%$ gangguan pada wanita dan $10 \%$ oleh keduanya (Konsensus Penanganan Infertilitas, 2013). Infertilitas pria dapat disebabkan oleh beberapa faktor meliputi gangguan produksi sperma terkait kelainan genetic (sindroma Klinefelter, delesi kromosom Y), Gangguan pada spermatogenesis, stereidogenesis, gangguan regulasi hormonal pada sel-sel testicular, kerusakan langsung terkait anatomi (cryptochidisme, varicocele) dan faktor idiopatik.

Keadaan infertilitas pria dapat diketahui melalui pemeriksaan analisis sperma dan pemeriksaan kadar testosterone (Khaidir, 2006). Testosteron merupakan hormon androgen utama yang diproduksi oleh sel leydig dalam testis (Jain et al., 2009). Analisis sperma dilakukan untuk memeriksa jumlah spermatozoa, motilitas (motilitas baik, motilitas kurang baik, dan tidak motil), morfologi spermatozoa (normal atau abnormal baik kepala, leher, maupun ekor), viabilitas (daya hidup), viskositas dan $\mathrm{pH}$ yang merupakan parameter standar pemeriksaan sperma (Wrather et al., 1997).

Telah banyak usaha yang dilakukan oleh pasangan suami istri infertil untuk mendapatkan keturunan, baik berupa pengobatan secara modern dan konvensional. Salah satu pengobatan modern yang dipakai yaitu penggunaan testosteron sebagai hormon terapi pengganti (testosterone replacement treatment) bagi penderita gangguan disfungsi seksual (Ponti et al., 2014). Akan tetapi penggunaan obat ini masih jarang dipakai, mengingat harga yang relatif mahal dan memberikan efek samping pusing, mual, muntah, tekanan darah meningkat, serta meningkatkan resiko penyakit jantung 
dan stroke apabila testosteron ini digunakan dalam jangka waktu lama (Decroli \& Kam, 2017).

Alternatif penggunaan tanaman obat sebagai penyubur pria sudah mulai dipakai di dunia medis. Di Indonesia sendiri, penggunaan ramuan tradisional untuk meningkatkan kesuburan sudah sering digunakan masyarakat berdasarkan pengalaman turun-menurun, namun belum ada dasar ilmiah yang jelas (Depkes, 1989). Salah satu tanaman yang sering dijadikan obat adalah daun gendola (Basella alba). Daun gendola digunakan sebagai obat wasir dan anti peradangan di negara India dan Cina (Kumar, Ahlawat, Kumar, \& Dilbaghi, 2015). Menurut Arokoyo yang melakukan penelitian dengan menggunakan tikus yang dibuat menjadi DM (diberikan streptozotocin $50 \mathrm{mg} / \mathrm{KgBB}$ secara intraperitoneal) menyatakan bahwa Basella alba memberikan efek antidiabetik (menurunkan kadar gula darah) dan efek profertility (meningkatkan kualitas sperma), terkait dengan kandungan antioksidan dan peningkatan hormon gonad (Arokoyo, 2017).

Penelitian di Kamerun menyatakan bahwa daun Basella alba dipakai untuk meningkatkan kesuburan pria. Pemurnian sel leydig yang didapatkan dari tikus jantan galur Sprague dawley yang diinkubasi dan diberi ekstrak Basella alba selama 4 jam memberikan efek peningkatan secara signifikan kadar testosteron, estradiol dan kadar aromaterase mRNA serta meningkatkan viabilitas sel leydig (Nantia et al., 2011).

Pada penelitian di Kamerun (Manfo et al., 2014) didapatkan hasil bahwa kemampuan ekstrak daun gendola yang diberikan sebanyak $1 \mathrm{mg} / \mathrm{KgBB}$ selama 30 hari pada tikus Wistar dan dilanjutkan pemberian ekstrak Carpolobia alba sebanyak 0,1 $\mathrm{mg} / \mathrm{kgBB}$ selama 60 hari memberikan hasil bahwa ekstrak daun ini dapat melawan efek toksik dari tikus yang diberi pestisida maneb (manganese ethylenebis / dithiocarbamate) dikarenakan adanya efek antioksidan pada ekstrak daun gendola. Beberapa senyawa yang terkandung dalam tanaman gendola memberikan efek antioksidan, seperti senyawa phenol, carotenoids, ascorbic acid, saponin, coumarin dan limonoid. Penelitian lain membuktikan bahwa ekstrak methanol Basella alba memberikan efek peningkatan aktivitas androgenik pada produksi testosteron di sel leydig (Manfo et al., 2015).

Penggunaan ekstrak daun gendola sudah banyak diteliti penggunaannya bersama dengan tanaman lain, berdasarkan uraian diatas maka penulis tertarik untuk meneliti penggunaan daun gendola sebagai obat untuk meningkatkan jumlah spermatozoa dan kadar testosteron dengan menggunakan pelarut n-heksan, methanol air dan etil asetat.

\section{Metode Penelitian}

Penelitian ini adalah penelitian eksperimental secara in vivo dengan menggunakan fraksi daun gendola (Basella alba) terhadap jumlah spermatozoa dan kadar testosteron tikus jantan. Tikus jantan yang digunakan dalam penelitian ini berjumlah 33 ekor yang semuanya telah memenuhi kriteria inklusi yang akan dibagi menjadi 11 kelompok. Penelitian ini dilaksanakan pada bulan Agustus sampai dengan November 2020 di Laboratorium Biokimia, Biologi Kedokteran dan Animal House Fakultas Kedokteran Universitas Sriwijaya. 
Perlakuan pada masing-masing kelompok yaitu dengan diberikan larutan fraksi Basella alba n-heksan $1 \mathrm{mg} / \mathrm{kgBB}$, n-heksan $5 \mathrm{mg} / \mathrm{kgBB}$, fraksi n-heksana dosis $10 \mathrm{mg} / \mathrm{kgBB}$, fraksi etil asetat dosis $1 \mathrm{mg} / \mathrm{kgBB}$, fraksi etil asetat $5 \mathrm{mg} / \mathrm{kgBB}$, fraksi etil asetat dosis $10 \mathrm{mg} / \mathrm{kgBB}$, fraksi methanol air dosis $1 \mathrm{mg} / \mathrm{kgBB}$, fraksi methanol air dosis 5 $\mathrm{mg} / \mathrm{kgBB}$, fraksi methanol air dosis $10 \mathrm{mg} / \mathrm{kgBB}$ diberikan secara oral selama 30 hari. kelompok kontrol negatif diberikan Na CMC 1\% sebanyak $1 \mathrm{cc}$ secara oral selama 30 hari. Kelompok kontrol dengan diberikan Testosteron Enanthate dengan dosis 5 $\mathrm{mg} / \mathrm{kgBB}$ yang dilarutkan dengan sesame oil / minyak wijen sebanyak 1 cc secara injeksi intramuscular di paha tikus pada hari ke 0 dan 12 .

1. Fraksi Daun Gendola (Basella alba)

Daun gendola (Basella alba) didapatkan dari Sringganis Balai tanaman obat Bogor dan mendapatkan sertifikat identifikasi keaslian tanaman dari LIPI Cibinong. Basella alba dikeringkan didalam rumah kaca Fakultas MIPA Universitas Sriwijaya selama 30 hari. Setelah daun kering, di blender dan terbentuk simplisia. Simplisia dimaserasi dengan menggunakan methanol 96\% selama 2 x 24 jam, kemudian dilakukan penyaringan dengan corong pisah dan diuapkan dengan rotary evaporator sehingga didapatkan pasta kental. Dari fraksi methanol ini dilanjutkan dengan membuat fraksi dengan menambahkan methanol air dengan perbandingan $1: 1$ sebanyak $200 \mathrm{ml}$. Selanjutnya dimasukkan ke dalam corong pisah, kemudian difraksinasi dengan menambahkan 200ml n-heksana, dikocok lalu didiamkan sampai terbentuk dua lapisan terpisah. Lapisan n-heksana dipisahkan ke dalam botol selai dan ditambahkan n-heksana baru pada lapisan methanol-air. Proses ini diulangi beberapa kali sampai larutan bewarna bening dengan cara yang sama.

Proses fraksinasi dilanjutkan dengan memakai pelarut etil asetat dengan cara dan volume yang sama utuk mendapatkan fraksi n heksan. Fraksi n-heksan cair, fraksi etil asetat cair, dan fraksi methanol-air diuapkan dengan Rotary evaporator sampai didapatkan fraksi kental dan keringkan dengan hair dryer sehingga didapatkan fraksi kering. Hasil fraksi yang didapatkan dapat dilakukan uji aktivitas fraksi untuk menilai fertilitas (jumlah spermatozoa dan kadar hormon testosteron) tikus.

2. Perlakuan pada Hewan Uji

a. Persiapan Hewan

Tikus jantan berusia 2-3 bulan diadaptasi terlebih dahulu selama seminggu serta diberi makan dan minum secara ad libitum, dimasukkan kedalam kandang yang ditutup dengan kassa dengan pengelompokan 3 tikus setiap kandang. Cahaya ruangan dikontrol setiap hari, diatur suhu dan kelembapan kandang $23-39^{\circ} \mathrm{C}$.

b. Pengelompokan Hewan Percobaan

Tikus dikelompokkan menjadi 11 kelompok dipilih secara acak masingmasing 3 ekor. dengan rincian kelompok diberi n-heksan $1 \mathrm{mg} / \mathrm{kgBB}$, n-heksan 5 $\mathrm{mg} / \mathrm{kgBB}$, fraksi $\mathrm{n}$-heksana dosis $10 \mathrm{mg} / \mathrm{kgBB}$, fraksi etil asetat $1 \mathrm{mg} / \mathrm{kgBB}$, fraksi etil asetat $5 \mathrm{mg} / \mathrm{kg} \mathrm{BB}$, fraksi etil asetat $10 \mathrm{mg} / \mathrm{kgBB}$, fraksi methanol air 1 $\mathrm{mg} / \mathrm{kgBB}$, fraksi methanol air $5 \mathrm{mg} / \mathrm{kgBB}$, fraksi methanol air $10 \mathrm{mg} / \mathrm{kgBB}$ 
diberikan secara oral selama 30 hari. Kelompok kontrol negatif diberikan $\mathrm{Na}$ CMC 1\% sebanyak 1 cc secara oral selama 30 hari. Kelompok kontrol dengan diberikan Testosteron Enanthate dengan dosis $5 \mathrm{mg} / \mathrm{kgBB}$ yang dilarutkan dengan sesame oil / minyak wijen sebanyak 1 cc secara injeksi intramuscular di paha tikus.

Setelah perlakuan pemberian fraksi daun gendola, pada hari ke-31 tiap kelompok diambil dahulu sampel darahnya melalui vena sinus orbita lalu simpan sampel darah dalam tabung darah EDTA yang telah disediakan. Kemudian tikus dinarkosis dengan kloroform, dibedah, lalu organ reproduksi yang meliputi testis, epididimis, diambil, dibersihkan lalu dilakukan pemisahan cauda epididimis dari testis dengan cara memotong bagian proksimal corpus epididimis dan bagian distal vas deferens. Selanjutnya, cauda epididimis dimasukkan ke dalam cawan petri yang berisi $1 \mathrm{ml} \mathrm{NaCL} 0,9 \%$, kemudian cauda epididimis dipotong-potong sampai halus dan diaduk dengan $\mathrm{NaCL}$ 0,9\% sehingga terbentuk suspensi spermatozoa.

c. Jumlah Spermatozoa

Suspensi spermatozoa yang telah diperoleh terlebih dahulu dibuat homogen dengan cara digetarkan dengan tangan atau diaduk dengan hati-hati dengan gelas pengaduk. Suspensi spermatozoa dihisap sebanyak 0,005 $\mathrm{ml}$ sampel, setelah itu cairan pengencer dihisap dalam pipet sampai tanda 1,01 .

Cara membuat suspensi spermatozoa yang homogen untuk pemeriksaan jumlah spermatozoa, yaitu dengan melihat terlebih dahulu jumlah sperma dengan pembesaran 400X perlapangan pandang. Jika didapatkan lebih dari 101 spermatozoa dalam satu kali lapangan pandang, maka buat pengenceran dengan perbandingan 1: $20(50 \mu \mathrm{L}$ semen: $950 \mu \mathrm{L} \mathrm{NaCl}$ 0,9\%) dan dihitung pada Grid 5,4 dan 6.

Suspensi spermatozoa diteteskan dari pipet, tepat pada pinggir gelas penutup itu hingga menyebar. Bilik hitung hemasitometer Improved Neubauer diletakkan dibawah mikroskop dengan perbesaran 400 kali. Kemudian konsentrasi spermatozoa pada bidang grid 4, 5, 6 dihitung sebanyak dua chamber (Cao, Lin, Li, \& Yuan, 2011). Selisih antara dua chamber tidak boleh melebihi jumlah yang diperbolehkan sesuai dengan tabel berikut 


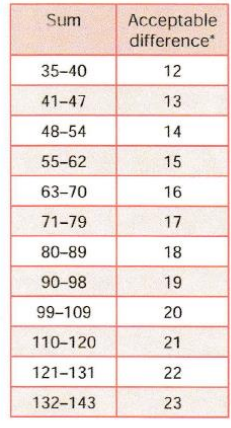

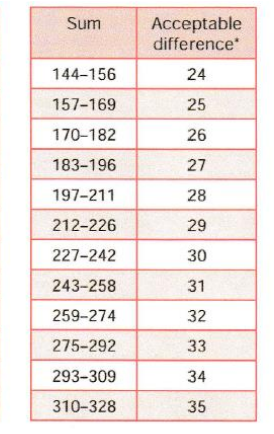

Gambar 1

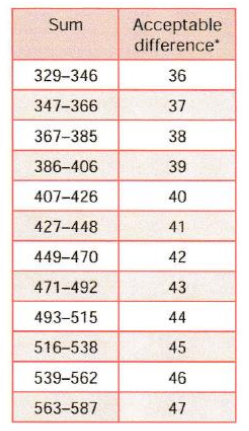

Selisih Perhitungan Jumlah Spermatozoa Menurut WHO (Cao, Lin, Li, \& Yuan, 2011)

Jumlahkan semua spermatozoa yang telah kita lihat pada grid 5, 4, dan 6 pada chamber 1 dan chamber 2 . Selisih antara chamber 1 dan 2 tidak boleh melebihi nilai yang ada pada tabel 1

Total perhitungan disubsitusi dalam rumus penentuan konsentrasi spermatozoa dalam milliliter $(\mathrm{ml})$ suspensi sekresi cauda epididimis sebagai berikut:

$\mathrm{N}=$ Jumlah total spermatozoa yang dihitung pada kotak grid 4, 5, 6 .

$\mathrm{n}=$ jumlah row/baris yang dihitung

Misalnya konsentrasi pada sampel $1+19$ (pengenceran 1: 20), Nilai N yang didapatkan pada chamber 1220 spermatozoa dan chamber 2218 spermatozoa, $(220-218=2)$. Penjumlahan $220+218=438$. Maka berdasarkan tabel 7 selisih antara chamber 1 dan 2 masih diperbolehkan.

Jumlah Spermatozoa $(\mathrm{C})=(\mathrm{N} / \mathrm{n}) \mathrm{X}(1 / \mathrm{v}) \mathrm{X}$ dilution factor X106

$\mathrm{C}=438 / 15 \times 1 / 20 \times 20$ spermatozoa per $\mathrm{nL}=29,2 \mathrm{X} 106$ Spermatozoa.

3. Prosedur Pemeriksaan Kadar Testosteron

Data kadar testosteron bebas didapatkan dengan cara:

a. Mengambil darah tikus sebanyak $2 \mathrm{ml}$ dengan kapiler mikrohematokrit dari sinus orbitalis, kemudian dimasukkan kedalam tabung reaksi

b. Tabung reaksi kemudian disentrifugasi dengan kecepatan 3500 rpm selama 15 menit untuk memisahkan serum dan sel-sel darah

c. Dengan menggunakan alat mini-Vidas, serum dan reagen ditempatkan dalam Reagent Strip siap pakai dan solid phase berupa Solid Phase Receptacle (SPR). Mini-Vidas adalah immunology analyzer yang bekerja secara otomatis dengan menggunakan teknologi pembacaan Enzyme-Linked Fluorescence Immuno-Assay (ELFA). Proses pengetesan dilakukan secara otomatis dan hasil pembacaan Fluorescent yaitu Relative Fluorescent Value (RFV) akan dikonversikan menjadi hasil akhir tes kualitatif dan kuantitatif. 


\section{Hasil dan Pembahasan}

1. Uji fitokimia

Uji fitokimia dilakukan di Laboratorium Biokimia Unsri untuk mengetahui senyawa yang terkandung di dalam fraksi daun gendola.

\section{Tabel 1}

\section{Hasil Uji Fitokimia Fraksi Daun Gendola}

\begin{tabular}{|c|c|c|c|c|c|}
\hline No & Uji Fitokimia & Kejadian & $\begin{array}{l}\text { Metanol } \\
\text { air }\end{array}$ & $\begin{array}{c}\text { Etil } \\
\text { asetat }\end{array}$ & $\begin{array}{c}\mathrm{N}- \\
\text { heksan }\end{array}$ \\
\hline \multirow[t]{2}{*}{1.} & $\begin{array}{l}\text { Alkaloid } \\
\text { a. Pereaksi } \\
\text { Dragendorf }\end{array}$ & Endapan warna merah jingga & + & + & - \\
\hline & b. Pereaksi Mayer & Endapan warna putih jingga & + & + & - \\
\hline 2. & Flavonoid & Terbentuk warna merah & + & + & - \\
\hline 3. & Tannin & Warna biru kehitaman & + & + & - \\
\hline 4. & Saponin & $\begin{array}{c}\text { Terbentuk busa yang mantap } \\
\text { dan tinggi }\end{array}$ & + & - & + \\
\hline 5. & Triterpenoid & Terbentuk cincin kecoklatan & + & - & - \\
\hline & Steroid & $\begin{array}{l}\text { Terbentuk cincin biru } \\
\text { kehijauan }\end{array}$ & - & + & + \\
\hline
\end{tabular}

Pada tabel di atas dapat disimpulkan bahwa fraksi metanol air mengandung senyawa alkaloid, flavonoid, triterpenoid, saponin dan tannin. Fraksi etil asetat mengandung senyawa alkaloid, flavonoid, steroid, dan tannin. Fraksi $\mathrm{n}$ heksan mengandung senyawa steroid dan saponin.

2. Karakteristik Sampel

a. Homogenitas Berat Badan Tikus

Hasil analisis uji homogenitas berat badan tikus diuji dengan menggunakan Levene test didapatkan bahwa $\mathrm{p}=0,078$ ( $\mathrm{p}>$ alpha) varians data berat badan tikus tidak berbeda bermakna antar kelompok perlakuan artinya berat badan tikus homogen. Sehingga pada persyaratan penelitian eksperimental terpenuhi.

\section{Tabel 2}

\section{Homogenitas Berat badan Tikus}

\begin{tabular}{cccc}
\hline Levene statistic & Df1 & Df2 & Sig. \\
\hline 2,042 & 10 & 22 & 0,078 \\
\hline
\end{tabular}

b. Pengaruh Fraksi Daun Gendola Terhadap Hormon Testosteron Tikus Jantan

Data hormon testosteron yang telah diperoleh dari pemeriksaan melalui alat mini VIDAS dari BBLK Palembang, analisis perbandingan hormon testosteron terhadap kelompok perlakuan diuji dengan menggunakan uji one way Anova didapatkan bahwa terdapat perbedaaan yang bermakna rerata kadar hormon 
testosteron pada seluruh kelompok perlakuan nilai $\mathrm{p}=0,000 \quad(\mathrm{p}<0,05)$. Hasil analisis dapat dilihat pada tabel 3 .

Tabel 3

Perbandingan Hormon Testosteron Setelah Pemberian Fraksi Aktif Daun Gendola (Basella Alba)

\begin{tabular}{cccc}
\hline Kelompok Perlakuan & N & Mean \pm SD & P value \\
n-heksan $1 \mathrm{mg} / \mathrm{KgBB}$ & 3 & $2,80 \pm 0,59$ & \\
n-heksan $5 \mathrm{mg} / \mathrm{KgBB}$ & 3 & $3,75 \pm 0,74$ & \\
n-heksan $10 \mathrm{mg} / \mathrm{KgBB}$ & 3 & $8,31 \pm 0,81$ & \\
etil asetat $1 \mathrm{mg} / \mathrm{kgBB}$ & 3 & $2,02 \pm 0,54$ & \\
etil asetat $5 \mathrm{mg} / \mathrm{kgBB}$ & 3 & $2,05 \pm 0,64$ & \\
etil asetat $10 \mathrm{mg} / \mathrm{kgBB}$ & 3 & $2,37 \pm 0,22$ & 0,000 \\
methanol air 1mg/kgBB & 3 & $3,71 \pm 0,38$ & \\
methanol air $5 \mathrm{mg} / \mathrm{kgBB}$ & 3 & $3,63 \pm 0,39$ & \\
methanol air10mg/kgBB & 3 & $5,48 \pm 2,18$ & \\
Testosteron enanthate & 3 & $14,05 \pm 1,3$ & \\
Na CMC 1\% & 3 & $0,40 \pm 0,10$ & \\
\hline
\end{tabular}

Uji One Way Anova $p<\alpha$

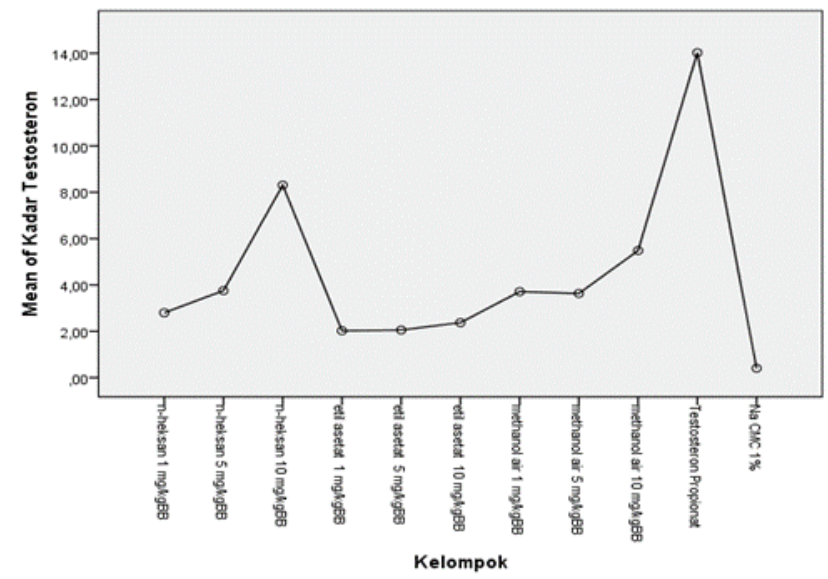

Gambar 2

Perbandingan Jumlah Spermatozoa Setelah Pemberian Fraksi Aktif Daun Gendola (Basella alba)

Hasil analisis perbandingan efektivitas jumlah spermatozoa terhadap kelompok perlakuan diuji dengan menggunakan uji One Way Anova didapatkan bahwa terdapat perbedaaan yang bermakna rerata jumlah spermatozoa pada seluruh kelompok perlakuan nilai $\mathrm{p}=0,000(\mathrm{p}<0,05)$. Hasil analisis dapat dilihat pada tabel 4. 


\section{Tabel 4 \\ Perbandingan Jumlah sperma Setelah Pemberian Fraksi Aktif daun Gendola} (Basella Alba)

\begin{tabular}{cccc}
\hline Kelompok Perlakuan & N & Mean \pm SD & P value \\
\hline n-heksan $1 \mathrm{mg} / \mathrm{KgBB}$ & 3 & $32,78 \pm 7,30$ & \\
n-heksan $5 \mathrm{mg} / \mathrm{KgBB}$ & 3 & $36,63 \pm 3,18$ & \\
n-heksan $10 \mathrm{mg} / \mathrm{KgBB}$ & 3 & $38,40 \pm 7,37$ & \\
etil asetat $1 \mathrm{mg} / \mathrm{kgBB}$ & 3 & $17,03 \pm 1,95$ & \\
etil asetat $5 \mathrm{mg} / \mathrm{kgBB}$ & 3 & $20,20 \pm 1,99$ & 0,000 \\
etil asetat $10 \mathrm{mg} / \mathrm{kgBB}$ & 3 & $16,58 \pm 5,41$ & \\
methanol air $1 \mathrm{mg} / \mathrm{kgBB}$ & 3 & $33,36 \pm 3,88$ & \\
methanol air $5 \mathrm{mg} / \mathrm{kgBB}$ & 3 & $25,43 \pm 1,26$ & \\
methanol air10mg/kgBB & 3 & $22,20 \pm 5,32$ & \\
Testosteron enanthate & 3 & $42,73 \pm 3,59$ & \\
Na CMC 1\% & 3 & $15,73 \pm 1,05$ & \\
\hline
\end{tabular}

Uji One Way Anova $p<\alpha$

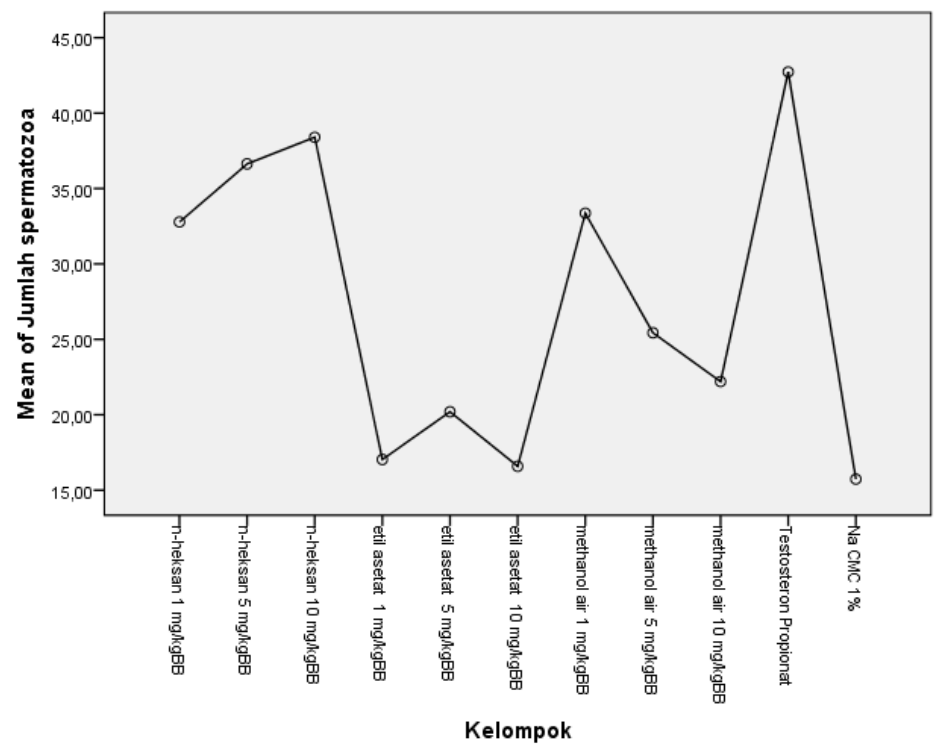

Pada analisis statistik dengan menggunakan uji One Way Anova didapatkan bahwa terdapat perbedaaan yang bermakna rerata kadar hormon testosteron nilai $\mathrm{p}=0,000(\mathrm{p}<0,05)$. Dilanjutkan dengan uji post hoc Games Howell didapatkan pada fraksi n-heksan $10 \mathrm{mg} / \mathrm{kgBB}$ didapatkan pvalue $=0,057$, sedangkan pada fraksi methanol air $10 \mathrm{mg} / \mathrm{kgBB}$ didapatkan pvalue $=0,066$. Hal ini berarti tidak berbeda bermakna dengan kontrol positif (testosteron enanthate), dengan kata lain pada dosis $10 \mathrm{mg} / \mathrm{kgBB}$ fraksi n-heksan dan methanol air $10 \mathrm{mg} / \mathrm{kgBB}$ mempunyai efektivitas yang sama dalam meningkatkan kadar hormon testosteron pada tikus jantan.

Hasil analisis perbandingan efektivitas jumlah spermatozoa terhadap kelompok perlakuan diuji dengan menggunakan uji One Way Anova didapatkan bahwa terdapat perbedaaan yang bermakna rerata jumlah spermatozoa pada seluruh kelompok perlakuan nilai $\mathrm{p}=0,000(\mathrm{p}<0,05)$. Kemudian dilanjutkan uji Post Hoc Games Howell, 
didapatkan jumlah spermatozoa pada masing-masing kelompok menunjukkan bahwa fraksi n-heksan dan methanol air pada dosis minimum (1 $\mathrm{mg} / \mathrm{kgBB})$ sudah menunjukkan tidak berbeda bermakna dengan kontrol positif (testosteron enanthate), dimana pvalue $=0,0631$ ( $p>0,05)$ dengan kata lain pada dosis rendah pun $n$-heksan dan methanol air sudah mempunyai efektivitas yang sama dalam meningkatkan jumlah spermatozoa pada tikus jantan yang terbukti secara statistic.

Berdasarkan penelitian Manfo, dosis Baesella alba yang digunakan adalah 1 $\mathrm{mg} / \mathrm{KgBB}$ selama 30 hari dapat meningkatkan kadar hormone testosterone. (Manfo et al., 2014). Mekanisme Basella alba ini adalah dengan masuknya zat-zat yang terkandung dalam tanaman ini secara oral, diserap dalam darah, masuk kedalam sirkulasi darah mempengaruhi hypothalamus yang menghasilkan Gonadthrophin Releasing Hormon (GnRH) memacu hipofisis anterior memproduksi FSH dan LH. FSH memacu sel sertoli menghasilkan inhibin dan Androgen Binding Protein (ABP). LH merangsang sel leydig yang berperan dalam produksi hormone testosterone (androgen). Testosteron yang dihasilkan oleh sel Leydig akan terikat dengan ABP yang berasal dari sel sertoli yang membantu proses spermatogenesis. Testosteron yang berada di epididymis akan membantu pematangan spermatozoa sehingga terbentuklah spermatozoa dewasa dengan motilitas dan morfologi yang optimal. Jika kadar testosterone rendah maka volume semen pun akan turun dan begitu juga dengan jumlah spermatozoa yang dihasilkan melalui proses spermatogenesis.

Peningkatan jumlah kadr testosterone dan jumlah spermatozoa ini disebabkan karena adanya senyawa saponin yang terdapat pada n-heksan dan methanol air, serta steroid yang didapatkan pada fraksi n-heksan. Senyawa steroid akan berguna dalam proses sintesa testosterone yang juga berpengaruh dalam proses spermatogenesis di testis. Peningkatan sterol sebagai akibat dari pemberian fraksi methanol air dan nheksan akan mengakibatkan meningkatnya sintesis testosterone. Testosteron yang dihasilkan mempengaruhi hipofisis untuk mempengaruhi $\mathrm{GnRH}$, merangsang hipofisis untuk menghasilkan FSH yang menghasilkan sel sertoli dan LH yang menghasilkan sel leydig yang juga menghasilkan hormone testosterone yang berperan dalam spermatogenesis. Dengan meningkatnya kadar hormone testosterone di dalam sirkulasi, maka sekaligus akan meningkatkan jumlah spermatozoa.

\section{Kesimpulan}

Dari hasil penelitian dan pembahasan dapat disimpulkan bahwa pemberian fraksi aktif daun gendola dapat meningkatkan jumlah spermatozoa dan kadar hormone testosterone.

Saran agar dapat dikembangkan penelitian ini selanjutnya dengan membuat preparat histologis dari tubulus seminiferus dan epididymis sehingga dapat melihat perkembangan seluruh staging dari spermatogenesis setelah pemberian fraksi daun gondola (Basella alba). 


\section{BIBLIOGRAFI}

Arokoyo, Dennis Seyi. (2017). Antidiabetic and profertility mechanisms of aqueous extract of Basella alba in male Wistar rats. Cape Peninsula University of Technology. Google Scholar

Cao, Xing Wu, Lin, Kai, Li, Cui Ying, \& Yuan, Chang Wei. (2011). A review of WHO Laboratory Manual for the Examination and Processing of Human Semen. Zhonghua Nan Ke Xue= National Journal of Andrology, 17(12), 1059-1063. Google Scholar

Decroli, Eva, \& Kam, Alexander. (2017). Dampak Klinis Thyroid-Stimulating Hormone. Jurnal Kesehatan Andalas, 6(1), 222-230. Google Scholar

Depkes, R. I. (1989). Materia Medika. Jilid V. Jakarta: Direktorat Jenderal Pengawasan Obat Dan Makanan.

Jain, Seema, Kamimoto, Laurie, Bramley, Anna M., Schmitz, Ann M., Benoit, Stephen R., Louie, Janice, Sugerman, David E., Druckenmiller, Jean K., Ritger, Kathleen A., \& Chugh, Rashmi. (2009). Hospitalized patients with 2009 H1N1 influenza in the United States, April-June 2009. New England Journal of Medicine, 361(20), 1935-1944. Google Scholar

Khaidir, Masrizal. (2006). Penilaian tingkat fertilitas dan penatalaksanaannya pada pria. Jurnal Kesehatan Masyarakat Andalas, 1(1), 30-34. Google Scholar

Kumar, Sandeep, Ahlawat, Wandit, Kumar, Rajesh, \& Dilbaghi, Neeraj. (2015). Graphene, carbon nanotubes, zinc oxide and gold as elite nanomaterials for fabrication of biosensors for healthcare. Biosensors and Bioelectronics, 70, 498503. Google Scholar

Manfo, Faustin Pascal Tsagué, Nantia, Edouard Akono, Béboy, Sara Nathalie Edjenguèlè, Moundipa, Paul Fewou, Pugeat, Michel, \& Wang, Paulus S. (2015). Medicinal Plants as Treatment Option of Male Reproductive Dysfunctions. 調適醫學, 7(2), 57-72. Google Scholar

Manfo, Faustin Pascal Tsagué, Nantia, Edouard Akono, Dechaud, Henri, Tchana, Angèle Nkouatchoua, Zabot, Marie Thérèse, Pugeat, Michel, \& Moundipa, Paul Fewou. (2014). Protective effect of Basella alba and Carpolobia alba extracts against maneb-induced male infertility. Pharmaceutical Biology, 52(1), 97-104. Google Scholar

Nantia, Edouard Akono, Travert, Carine, Manfo, Faustin Pascal T., Carreau, Serge, Monsees, Thomas K., \& Fewou Moundipa, Paul. (2011). Effects of the methanol extract of Basella alba L (Basellaceae) on steroid production in Leydig cells. International Journal of Molecular Sciences, 12(1), 376-384. Google Scholar 
Pasaribu, S., Lubis, M., Arsyad, F., Barus, N., \& Sutanto, A. H. (1987). Gastroenteritis in the Pediatric Ward of Dr. Pirngadi Hospital Medan in 1983. Paediatrica Indonesiana, 27(3-4), 43-54. Google Scholar

Ponti, Massimo, Perlini, Rossella Angela, Ventra, Vincenzo, Grech, Daniele, Abbiati, Marco, \& Cerrano, Carlo. (2014). Ecological shifts in Mediterranean coralligenous assemblages related to gorgonian forest loss. PloS One, 9(7), e102782. Google Scholar

Wrather, J. Allen, Anderson, T. R., Arsyad, D. M., Gai, J., Ploper, L. D., Porta-Puglia, Angelo, Ram, H. H., \& Yorinori, J. T. (1997). Soybean disease loss estimates for the top 10 soybean producing countries in 1994. Plant Disease, 81(1), 107-110.

\section{Copyright holder:}

Fitrianti Yuni (2022)

First publication right:

Syntax Literate: Jurnal Ilmiah Indonesia

This article is licensed under:

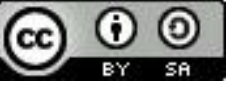

